\title{
Hantavirus Infections in Light of Current Knowledge
}

\author{
Güncel Bilgiler Işı̆̆ında Hantavirüs Enfeksiyonları
}

\section{Selçuk KAYA}

Karadeniz Technical University Faculty of Medicine, Department of Infectious Diseases and Clinical Microbiology, Trabzon, Turkey

\section{Abstract}

Hantavirus is an enveloped virus with an RNA genome comprised of three negative-sense, single-stranded segments and belongs to the genus Hantavirus in family Bunyaviridae. Human infections are seen in two different clinical presentations: "Hemorrhagic fever with renal syndrome" and "Hantavirus cardiopulmonary syndrome". However, the main pathogenic mechanism is vascular endothelial dysfunction; viral properties and host immunogenetic factors both play a role in pathogenesis. Early diagnosis and supportive treatment are crucial to prevent mortality. Fluid/ electrolyte and oxygen therapy, renal replacement, regulation of blood pressure, and blood or blood products replacement are the main components of supportive treatment. Although ribavirin is controversial in the specific treatment, some studies have suggested that it may be beneficial, especially during the oliguric phase. Favipiravir and icatibant are other effective drugs in the treatment, and the use of $\alpha v \beta 3$ integrin inhibitors is also suggested. In recent years, monoclonal antibodies have been proposed for treatment as well as prophylaxis. DNA vaccines prepared with new technologies have good efficacy, enhancing the neutralizing antibody response. The next major breakthrough in Hantavirus immunization will be a vaccine that is effective against all viral subtypes.

Keywords: Hantavirus infections, favipiravir, icatibant, therapeutics, prevention and control

\section{Öz}

Hantavirüs, Bunyaviridae ailesinin Hantavirus genusunda yer alan üç segmentli, negatif polariteli RNA genomuna sahip olan zarflı bir virüstür. İnsanlarda neden olduğu enfeksiyonlar; "Hantavirüs renal sendromla seyreden kanamalı ateş" ve "Hantavirüs kardiyopulmoner sendrom" olarak bilinen iki farklı klinik şekilde görülmektedir. Vasküler endotelyal fonksiyon bozukluğu patogenezdeki temel mekanizma olup; virüse ait özellikler ile birlikte konağa ait immünogenetik faktörlerin birlikte rol aldığı düşünülmektedir. Hastalıkta erken tanı ve uygun destek tedavisinin verilmesi mortalitenin önlenmesinde etkilidir. Gerekli sıvı-elektrolit desteğinin sağlanması, renal replasman, oksijen desteği, kan basıncı regülasyonu, kan veya kan ürünü desteğinin sağlanması destek tedavisinin ana unsurlarıdır. Spesifik tedavide ribavirinin kullanımı tartışmalı olmakla birlikte, bazı çalışmalarda özellikle oligürik fazda kullanımı yararlı görülmektedir. Favipiravir ve icatibant tedavide etkili bulunan diğer ilaçlar olup, $\alpha v \beta 3$ integrinleri inhibe eden ilaçların da tedavide etkili olabileceği düşünülmektedir. Son yıllarda monoklonal antikorların tedavide kullanımının yanı sıra profilakside de etkili olabileceği bildirilmektedir. Yeni teknolojilerle hazırlanan DNA aşılarının primatların dışında insanlarda da yüksek nötralizan antikor cevabı oluşturarak oldukça etkili olabildiği görülmüştür. Aşılarla ilgili en önemli gelecek beklentisi tüm subtiplere karşı etkili olan aşının geliştirilmesidir. Anahtar Kelimeler: Hantavirüs enfeksiyonları, favipiravir, icatibant, tedavi bilimi, önleme ve kontrol 


\section{Introduction}

Hantaviruses are enveloped viruses in the Hantavirus genus of the Bunyavirus family with a genome consisting of three negative-sense RNA segments $s^{[1,2]}$. The reservoir is small mammals, through which the infection is transmitted to humans ${ }^{[1,2]}$. Transmission to humans usually occurs through inhalation of particles contaminated with rodent urine, saliva, and feces, and more rarely through rodent bites ${ }^{[1,2]}$. Changes in blood coagulation, vasodilation, blood extravasation resulting from capillary barrier dysfunction, and triggering of inflammatory process are all pathogenic mechanisms of hantavirus-induced disease ${ }^{[3-5]}$.

Human infections have two different clinical manifestations: hemorrhagic fever with renal syndrome (HFRS), seen in Asia and Europe, and Hantavirus cardiopulmonary syndrome (HCPS), which occurs in the U.S. with mortality rates of up to $50 \% 0^{[6]}$. It is estimated that there are more than 20,000 hantavirus cases annually worldwide, most of which are in Asia ${ }^{[7]}$.

In addition to the epidemiology, clinical features, and diagnosis of the disease, this article will also discuss the pathogenesis, prevention, and treatment in light of current studies, and will address future prospects.

\section{Epidemiology}

Hantaviruses are negative-stranded RNA viruses of the Bunyaviridae family. Contrary to other members of this family, they are not transmitted to humans via arthropods. Small animals, however, can act as reservoirs. Twenty-eight of the known 40 hantavirus strains are known to be pathogenic in humans ${ }^{[6]}$. Each is associated with a different host rodent. The geographical distribution of the different hantavirus strains is related to the varying distribution of rodent species. The incidence of human infection increases in parallel with the rate of infection in rodents; transmission to humans usually occurs through aerosolization of vector excretions such as urine, feces, and saliva, and more rarely through the bite of an infected animal ${ }^{[7]}$. The main factors affecting the viability of the virus are ambient heat, humidity, ultraviolet light/sunlight and the organic content of contaminated fluids. Certain groups such as forest workers, campers, and soldiers constitute a high-risk group due to the likelihood of exposure to rodents carrying the virus ${ }^{[6]}$. Traditionally, human-to-human transmission was not believed to be a route of infection; however, this belief was challenged when transmission was documented during an outbreak of HCPS caused by the Andes virus (ANDV) in Argentina. The main risk factors for secondary infection in humans are sleeping in the same room with an index patient, sexual contact, and exposure to body fluids ${ }^{[6]}$. Transmission while caring for prodromal patients has also been reported ${ }^{[6,8]}$. The majority of HFRS cases occur in Southeast Asia and Russia, and there are many viral subtypes that differ in their geographical distributions. Of these, the Hantaan virus (HTNV) and Seoul viruses are the most common in Asia, while the Puumala virus (PUUV) and Dobrava viruses (DOBV) are the most common in Europe. Hantavirus cardiopulmonary syndrome is caused by subtypes such as the Sin Nombre (SNV), Andes, Negra, Laguna, and New York viruses ${ }^{[9]}$. The viral subtype is directly related to clinical course and mortality, thus making it crucial to identify the etiological agent in infected patients ${ }^{[10]}$. The first study to show the presence of hantaviruses in Turkey was a 2004 study in which the PUUV hantavirus subtype was detected in rodents in the northeast and western regions of Turkey ${ }^{[11]}$. Another important seroprevalence study investigating hantavirus epidemiology demonstrated the presence of the DOBV, PUUV, and Saaremaa subtypes in serum samples collected from people in Giresun ${ }^{[12]}$. Clinically, the first cases of hantavirus infection in Turkey were reported in 2009, and hantaviruses have been commonly featured in case reports since then ${ }^{[13-15]}$.

\section{Pathogenesis}

\section{Viral Characteristics}

Human and animal studies of hantavirus infection have demonstrated the presence of viral antigens primarily in pulmonary and renal endothelial cells and macrophages, though they have also been detected in several other organs ${ }^{[6]}$. Animal studies of hantaviruses are limited by the fact that they do not cause disease in their natural hosts, which has hindered efforts to elucidate its pathogenesis ${ }^{[6]}$.

Although the exact pathogenesis remains unclear, organ dysfunction stemming in part from capillary leak is believed to play a key role in HTNV infections, which are responsible for a large portion of cases of HFRS ${ }^{[3,4,7]}$. It is believed that HFRS is a type of systemic inflammatory response syndrome and that the hypotensive phase which occurs during the disease course causes a shock-like condition ${ }^{[7,16]}$. Vascular endothelial dysfunction is the main mechanism in the pathogenesis, resulting in increased vascular permeability and cellular extravasation of plasma, with clinical manifestations such as hemorrhage as well as hemoconcentration, abdominal pain, and shock ${ }^{[16]}$.

However, host immune and genetic factors must also be considered together with viral characteristics when discussing pathogenesis ${ }^{[6,16]}$.

\section{Immune Factors}

The immune response is believed to play an especially significant role in pathogenesis ${ }^{[6]}$. Numerous past studies focusing on the adaptive immune response showed that antibodies and immunocomplexes against the virus were present at high 
titers in the blood of infected patients ${ }^{[6]}$. Studies have shown that innate immunity itself is antiviral and triggers adaptive immunity ${ }^{[6,8]}$. The importance of Toll-like receptors has been particularly emphasized. Toll-like receptors elicit a strong immune response and trigger the release and overproduction of type 1 interferon and inflammatory cytokines, which are critical for host defense ${ }^{[8]}$. Complement system activation was reported to correlate with disease severity in patients with PUUV infection. Natural killer cells constitute another defensive weapon that play a role in pathogenesis by contributing to the capillary leak seen in $\mathrm{HFRS}^{[8]}$. High titers of neutralizing antibodies which develop in the acute phase favorably affect the clinical course of the disease and also protects against reinfection, persisting at detectable levels for up to 35 years after illness. It is believed that after the convalescent phase, patients will be protected for a lifetime, and no cases of reinfection have been reported to date ${ }^{[8]}$. Further studies are expected to focus on the pathogenesis of innate immunity ${ }^{[6]}$.

\section{Genetic Factors}

Genetic factors are known to play a role in susceptibility to infection, and some HLA types have been associated with more severe disease course. The HLA-B*8 DRB1*03:02 haplotype has been shown to be associated with a severe course in PUUV and ANDV infections. HLA-B ${ }^{*} 35$ has been associated with fatal DOBV and SNV infections in particular ${ }^{[6]}$.

\section{Recent Studies on Pathogenesis}

A study by Papa et al. ${ }^{[1]}$ demonstrated the relationship between disease severity and plasma and urine levels of vascular endothelial growth factor (VEGF) and soluble vascular endothelial growth factor receptor 2 (sVEGFR2) in PUUV and DOBV infections, highlighting the dual roles of these molecules in pathogenesis ${ }^{[1]}$. Using a human intestinal epithelium (Caco-2) cell culture, they determined that the small intestine epithelium was susceptible to hantavirus infection. They also reported that PUUV and DOBV were able to survive in the human gastric passage and proliferate in Caco-2 cells $s^{[1]}$.

Another study conducted in Sweden reported that the strong inhibition of human umbilical vein endothelial cells due to induction of apoptosis is an important pathogenic mechanism ${ }^{[1]}$.

In their study on the ANDV, Gorbunova et al. ${ }^{[17]}$ showed that nucleocapsid (N) proteins bound E3 ubiquitin ligase TRIM21 and that interferon-beta was synergistically inhibited by TRIM21 and $\mathrm{N}$ proteins. They also reported TRIM21 as a new target region regulated by interferon-beta for ANDV.

A German study focused on the significance of neutrophil activation and CD8+ $T$ cells in pathogenesis ${ }^{[11]}$. The authors state that acceleration and aggregation of functional CD8+ $T$ cells in particular causes hantavirus-related disease. These cells directly interact with hantavirus-infected endothelial cells to increase microvascular leakage via tumor necrosis factor- $\alpha$, as well as indirectly promote the activation of immune cells such as neutrophils, which have an important role in disease development ${ }^{[18]}$.

In their study on ANDV, Grvrilovskaya et al. ${ }^{[3]}$ showed that pulmonary microvascular endothelial cells activate RhoA, a vascular permeability trigger, and lead to cell enlargement by preventing RhoA from suppressing the mTOR signal response. Nucleocapsid proteins control endothelial cell permeability response by interacting with the TSC2 (tuberous sclerosis complex) and Rac/RhoA regulatory proteins ${ }^{[3]}$. This can be seen as a potential treatment approach to resolve the vascular leak associated with hantavirus infections ${ }^{[3]}$. Another study utilizing a mouse cell line showed that the virulence of HTNV strains decreased in Vero E6 cells after serial passaging due to amino acid changes in the viral $\mathrm{N}$ proteins and RNA polymerase, and low-virulence strains proliferated faster in Vero cells ${ }^{[1]}$.

\section{Diagnosis}

It is critical to evaluate epidemiological features together with clinical and laboratory findings when diagnosing hantavirus infections ${ }^{[6]}$. Findings such as high fever, headache, back and abdominal pain, leukocytosis, thrombocytopenia, increased serum creatinine, proteinuria, and hematuria should raise suspicion of hantavirus. However, in cases with mild to moderate clinical features, early findings may be nonspecific and should not be relied on ${ }^{[6]}$.

The laboratory diagnosis of acute disease is based on serology. $\operatorname{lgM}$ and usually $\lg G$ antibodies are detected at disease onset in all patients ${ }^{[6]}$. While indirect IgM and IgG ELISA is commonly used for diagnosis, IgM capture ELISA has even higher specificity ${ }^{[6]}$. Indirect fluorescence assay is also used for diagnosis, but has lower specificity. Rapid immunochromatographic $\operatorname{lgM}$ antibody tests have also been developed and are available as commercial kits ${ }^{[6]}$.

Diagnosis of an early hantavirus infection (before antibodies become positive) can be established by detecting the viral genome with reverse transcriptase-polymerase chain reaction in the patient's serum and blood. The test can also be applied quantitatively and can be used to determine viral subtype. Although the level of viremia varies, acute cases are usually positive. It has been shown that viral load is higher in severe cases $^{[6]}$.

In Turkey, serum samples collected from patients for hantavirus diagnosis are sent to the National Public Health Virology Laboratory in Ankara, where ELISA and immunoblot tests are used to establish a definitive diagnosis of hantavirus infections, and viral subtype can also be identified ${ }^{[19]}$. 


\section{Clinical Findings}

The clinical presentation of HFRS is characterized by fever, hypotension, hemorrhage, and acute renal failure. The course of the disease is typically divided into five distinct phases: the febrile, hypotensive shock, oliguria, polyuria, and convalescent phases $^{[7]}$. These phases may overlap in severe cases, and some may be absent in mild cases. Laboratory findings in the acute phase include anemia, leukocytosis, thrombocytopenia, elevated serum creatinine and liver enzymes, proteinuria, and hematuria ${ }^{[7]}$. While most patients are able to fully recover, sequelae such as headache, hyperhidrosis, insomnia, hemorrhage, and hyperdiuresis may persist in some severe $\operatorname{cases}^{[7]}$.

The majority of patients develop kidney damage, which usually occurs in the form of tubulointerstitial nephritis following infiltration of inflammatory cells. Death usually occurs in the oliguric phase in severe cases, and these patients often require dialysis ${ }^{[7]}$.

Thrombocytopenia is one of the most important and basic findings observed in the disease; it has high diagnostic significance and may persist throughout the disease. This finding has also been associated with severe renal failure in acute HTNV cases $^{[7]}$.

Other manifestations may include pulmonary, cardiac, endocrine, central nervous system, and ocular findings ${ }^{[7]}$.

The clinical picture of HCPS, which mostly occurs in the Americas, includes a high risk of mortality (about 50\%), and follows a course of flu-like symptoms following a febrile phase lasting about five days ${ }^{[6,8]}$. By the time patients present to a hospital for specific symptoms like cough, dyspnea, tachycardia, and hypotension, their disease is usually at an advanced stage. Approximately half of the patients exhibit rapidly progressive pulmonary edema caused by capillary leak and low cardiac output, accompanied by dyspnea, cough, tachycardia, and hypotension. The subsequent cardiogenic shock is the main cause of death in these patients ${ }^{[8]}$.

\section{Treatment}

\section{Antiviral Drugs}

Interferon-alpha, steroids, cyclophosphamide, and ribavirin (1-beta-D-ribofuranosyl-1,2,4-triazole-3-carboxamide) have all been used for treatment due to their differing mechanisms of action ${ }^{[7]}$. Clinical trials have shown that ribavirin may be effective in HFRS if started early ${ }^{[7]}$. A slight increase in mortality was reported in HFRS patients taking ribavirin, while there was no difference in mortality among HCPS patients ${ }^{[20]}$. Rusnak et al. ${ }^{[21]}$ recommended the use of ribavirin, especially in the oliguric phase, claiming that ribavirin treatment during this phase could prevent mortality.
Mertz et al. ${ }^{[22-24]}$ conducted trials evaluating the antiviral and anti-inflammatory activity of intravenous ribavirin, methylprednisolone, and immune plasma obtained by plasmapheresis and their role in the supportive care of HCPS patients, as well as retrospectively investigating a case series treated with extracorporeal membrane oxygenation (ECMO). They stated that ECMO can reduce the risk of death in severe cases of HCPS, but cited the risk of morbidity and mortality and its relative inaccessibility as drawbacks of this treatment ${ }^{[23]}$. including 60 patients indicated that parenterally administered methylprednisolone was not effective for treatment. In another randomized controlled double-blind study involving 36 (23 serologically proven) HCPS patients in North America, Mertz et al. ${ }^{[24]}$ concluded that intravenous ribavirin was not effective in these patients.

Recently it is reported that icadibant may be effective in infections caused by PUUV and many other hantavirus subtypes by preventing the binding of bradykinin ${ }^{[25]}$. Favipiravir (T-705, 6-fluoro-3-hydroxy-2-pyrazinecarboxamide) has been shown to be highly active against many Bunyaviruses via inhibiting viral replication and cytopathic effect ${ }^{[26,27]}$. A murine monoclonal antibody developed for the treatment of HTNV infections was administered as a single-dose intravenous injection to healthy volunteers in a clinical trial, and was shown to be effective against HTNV both in vitro and in vivo ${ }^{[28]}$. Thus, it is believed that monoclonal antibodies may be a candidate for effective treatment of HFRS ${ }^{[29,30]}$. Neutralizing antibodies administered early may also play a protective role against the disease ${ }^{[7]}$.

Studies have also been conducted on small inhibitor molecules. For example, drugs that inhibit $\alpha v \beta 3$ integrins may be used in treatment ${ }^{[29]}$. In addition, other molecules such as VEGFR2 and 'Src family kinases' may be therapeutic by inhibiting the endothelial cell permeability associated with ANDV ${ }^{[4]}$. However, further studies are needed to demonstrate the therapeutic potential of these molecules.

\section{Supportive Therapy}

Early diagnosis, intensive care, and supportive therapy have greatly reduced mortality due to hantavirus infections, with rates of less than $1 \%$ for certain subtypes ${ }^{[7,30,31]}$. Maintaining fluid and electrolyte balance is the key principle of treatment ${ }^{[7]}$. Other critical issues are improving renal function, providing adequate oxygenation, and regulating blood pressure ${ }^{[7]}$. Continuous renal replacement therapy is currently a very important approach in patients with acute respiratory distress syndrome, multiorgan failure, fluid overload, pulmonary edema, severe electrolyte abnormality, cerebropathy, and acute kidney injury (AKI) ${ }^{[7,30]}$. Intermittent hemodialysis is preferred by clinicians for the treatment of AKI patients without hemodynamic instability, and fatal complications are less common in this approach ${ }^{[7]}$. 
Blood products, especially thrombocyte suspensions, can be used for patients with obvious hemorrhage or in severe cases presenting with thrombocytopenia ${ }^{[6,30-32]}$.

\section{Prognosis}

Multiple factors influence prognosis in hantavirus infections. Viral subtype is one of the most important factors; mortality can be as high as 40\% for subtypes such as SNV, which is responsible for HCPS, versus $1 \%$ or less in infections caused by PUUV ${ }^{[10]}$. Various other factors such as age, sex, humoral immune response, genetic factors, clinical and laboratory findings, transfusion, the need for mechanical ventilation, antiviral therapy and immunotherapy effect the prognosis ${ }^{[10]}$.

\section{Prevention}

Living in forested and rural areas is an important risk factor for the disease, and occupational groups which are at risk include construction and forest workers, farmers, and soldiers ${ }^{[6]}$. Rodent control is the primary protective measure. Rodent burrows and food sources in proximity to human residences must be destroyed, and potentially contaminated areas should be avoided. Apart from these standard measures, the only method of prevention is vaccination ${ }^{[6]}$.

\section{Preventive Vaccines and Future Prospects}

Preventive vaccines against hantavirus infections include HFRS and HCPS DNA vaccines, which are prepared using technologies such as gene guns and intramuscular electroporation ${ }^{[1]}$. These vaccines elicit a neutralizing antibody response with high titers in animals and non-human primates ${ }^{[1]}$. Hooper et al..$^{[32]}$ showed that DNA vaccines prepared from the M segment of HTNV and PUUV and delivered by electroporation, in which application of a brief but strong electric current creates transient nanometric pores in cell membranes, were safe and immunogenic and were able to elicit an adequate neutralizing antibody response. This open-label phase 1 trial included 31 participants whose serum antibody levels were measured, and no serious side effects of the vaccine were observed ${ }^{[32]}$. The growing interest in vaccine trials is evident, with one of the main goals being the development of a vaccine that is effective against different subtypes. The development of new vaccines against hantavirus infections will be based on the use of recombinant virus proteins, recombinant viruses, or DNA vaccines.

There is also a need for new, more effective antiviral drugs, and studies investigating the mechanism of capillary leak are anticipated in the future ${ }^{[1]}$.

\section{Ethics}

Peer-review: Externally and internally peer-reviewed.
Financial Disclosure: The author declared that this study received no financial support.

\section{References}

1. Papa A, Vaheri A, LeDuc JW, Krüger DH, Avšič-Županc T, Arikawa J, Song JW, Markotić A, Clement J, Liang M, Li D, Yashina LN, Jonsson CB, Schmaljohn CS. Meeting report: Tenth International Conference on Hantaviruses. Antiviral Res. 2016;133:234-41.

2. Kruger DH, Figueiredo LT, Song JW, Klempa B. Hantaviruses--Globally emerging pathogens. J Clin Virol. 2015;64:128-36.

3. Grvrilovskaya, IN, Gorbunova, EE, Mackow, NA, Mackow ER. Hantaviruses direct endothelial cell permeability by sensitizing cells to the vascular permeability factor VEGF, while angiopoietin 1 and sphingosine 1-phosphate inhibit Hantavirus-directed permeability. J Virol. 2008;82:5797-806.

4. Gorbunova, EE, Gavrilovskaya IN, Pepini, T, Mackow ER. VEGFR2 and Src kinase inhibitors suppress Andes Virus-induced endothelial cell permeability. J Virol. 2011:85:2296-303.

5. Jiang $H$, Zheng $X$, Wang $L$, Du $H$, Wang $P$, Bai X. Hantavirus infection: a global zoonotic challenge. Virol Sin. 2017;32:32-43.

6. Avšič-Županc T, Saksida A, Korva M. Hantavirus infections. Clin Microbiol Infect. 2015;22:1-11.

7. Jiang H, Du H, Wang LM, Wang PZ, Bai XF. Corrigendum: Hemorrhagic Fever with Renal Syndrome: Pathogenesis and Clinical Picture. Front Cell Infect Microbiol. 2016;6:178.

8. Manigold T, Vial P. Human hantavirus infections: epidemiology, clinical features, pathogenesis and immunology. Swiss Med Wkly. 2014;144:w13937.

9. Jonsson $\mathrm{CB}$, Figueiredo $\mathrm{LT}$, Vapalahti 0 . A global perspective on hantavirus ecology, epidemiology, and disease. Clin Microbiol Rev. 2010;23:412-41.

10. Kaya S. Prognostic factors in hantavirus infections. Mikrobiyol Bul. 2014:48:179-87.

11. Laakkonen J, Kallio-Kokko H, Oktem MA, Blasdell K, Plyusnina A, Niemimaa J, Karataş A, Plyusnin A, Vaheri A, Henttonen H. Serological survey for viral pathogens in Turkish rodents. J WildI Dis. 2006;42:672-6.

12. Ertek M, Buzgan T; Refik Saydam National Public Health Agency; Ministry of Health, Ankara, Turkey. An outbreak caused by hantavirus in the Black Sea region of Turkey, January-May 2009. Euro Surveill. 2009;14:19214.

13. Kaya S, Yılmaz G, Erensoy S, Yağçı Çağlayık D, Uyar Y, Köksal I. Hantavirus infection: two case reports froma province in the Eastern Black Sea Region, Turkey. Mikrobiyol Bul. 2010;44:479-87.

14. Öngürü $P$, Yılmaz $S$, Akıncı E, Özdemir B, But $A$, Yetkin $A$, Bodur H. Rena sendrom ile seyreden kanamalı ateş: İki olgu sunumu. Turk Hij Den Biyol Derg. 2011;68:35-9.

15. Gozalan A, Kalaycıoğlu H, Uyar Y, Sevindi DF, Turkyilmaz B, Çakir V, Cindemir C, Unal B, Yağçi-Çağlayik D, Korukluoglu G, Ertek M, Heyman P, Lundkvist $\AA$. Human puumala and dobrava hantavirus infections in the Black Sea region of Turkey: a cross-sectional study. Vector Borne Zoonotic Dis. 2013;13:111-8.

16. Hayasaka, D, Maeda, K, Ennis FA, Terajima, M. Increased permeability of human endothelial cell line EA.hy926 induced by hantavirus-specific cytotoxic T lymphocytes. Virus Res. 2007;123:120-7.

17. Gorbunova EE, Simons MJ, Gavrilovskaya IN, Mackow ER. The Andes Virus Nucleocapsid Protein Directs Basal Endothelial Cell Permeability by Activating RhoA. MBio. 2016;25;7:e01747.

18. Kobak L, Raftery MJ, Voigt $S$, Kühl AA, Kilic $E_{1}$ Kurth $A$, Witkowski $P$ Hofmann J, Nitsche A, Schaade L, Krüger DH, Schönrich G. Hantavirusinduced pathogenesis in mice with a humanized immune system. J Gen Virol. 2015;96:1258-63.

19. Kaya S, Çağlayık DY, Uyar Y, Yılmaz H, Engin A, Öngürü P, Yılmaz G, Köksa I. Can hantavirus infections be predicted on admission to hospital? J Med Virol. 2012;84:1790-6. 
20. Moreli ML, Marques-Silva AC, Pimentel VA, da Costa VG. Effectiveness of the ribavirin in treatment of hantavirus infections in the Americas and Eurasia: a meta-analysis. Virusdisease. 2014;25:385-9.

21. Rusnak, JM, Byrne WR, Chung KN, Gibbs PH, Kim T, Boudreau EF, Cosgriff T, Pittman P, Kim KY, Erlichman MS, Rezvani DF, Huggins JW. Experience with intravenous ribavirin in the treatment of hemorrhagic fever with renal syndrome in Korea. Antiviral Res. 2009;81:68-76.

22. Vial PA, Valdivieso $F$, Calvo $M$, Rioseco $M L$, Riquelme $R$, Araneda $A$, Tomicic V, Graf J, Paredes L, Florenzano M, Bidart T, Cuiza A, Marco C, Hjelle B, Ye C, Hanfelt-Goade D, Vial C, Rivera JC, Delgado I, Mertz GJ; Hantavirus Study Group in Chile. A non-randomized multicentre trial of human immune plasma for treatment of hantavirus cardiopulmonary syndrome caused by Andes virus. Antivir Ther. 2015;20:377-86.

23. Vial PA, Valdivieso F, Ferres $M$, Riquelme $R$, Rioseco $M L$, Calvo $M$, Castillo $C$, Díaz R, Scholz L, Cuiza A, Belmar E, Hernandez C, Martinez J, Lee SJ, Mertz GJ; Hantavirus Study Group in Chile. High-dose intravenous methylprednisolone for hantavirus cardiopulmonary syndrome in Chile: a double-blind, randomized controlled clinical trial. Clin Infect Dis. 2013;57:943-51.

24. Mertz GJ, Miedzinski L, Goade D, Pavia AT, Hjelle B, Hansbarger CO, Levy $H_{\text {, }}$ Koster FT, Baum K, Lindemulder A, Wang W, Riser L, Fernandez H, Whitley RJ; Collaborative Antiviral Study Group. Placebo-controlled, double-blind trial of intravenous ribavirin for the treatment of hantavirus cardiopulmonary syndrome in North America. Clin Infect Dis. 2004;1;39:1307-13.

25. Vaheri $A$, Strandin $T$, Jääskeläinen $A J$, Vapalahti $O$, Jarva $H$, Lokki $M L$, Antonen J, Leppänen I, Mäkelä S, Meri S, Mustonen J. Pathophysiology of a severe case of Puumala hantavirus infection successfully treated with bradykinin receptor antagonist icatibant. Antiviral Res. 2014;111:23-5.
26. Gowen $B B$, Wong $M H$, Jung $K H$, Sanders $A B$, Mendenhall $M$, Bailey KW, Furuta $Y$, Sidwell RW. In vitro and in vivo activities of T-705 against arenavirus and Bunyavirus infections. Antimicrob Agents Chemother. 2007;51:3168-76.

27. Safronetz $D$, Falzarano $D$, Scott DP, Furuta $Y$, Feldmann $H$, Gowen BB. Antiviral efficacy of Favipiravir against two prominent etiological agents of Hantaviruses pulmonary syndrome. Antimicrob Agents Chemother. 2013;57:4673-80

28. Xu R, Yang XY, Yang DF, Zou CY, Gong PL, Zeng FD. Phase I Evaluation of the safety and pharmacokinetics of a single-dose intravenous injection of a murine monoclonal antibody against Hantaan Virus in healthy volunteers. Antimicrob Agents Chemother. 2009;53:5055-9.

29. Hall PR, Leitão A, Ye C, Kilpatrick K, Hjelle B, Oprea TI, Larson RS Small molecule inhibitors of hantavirus infection. Bioorg Med Chem Lett.2010;20:7085-91.

30. Kostakoglu U, Yılmaz G, Volkan S, Sökel SK, Kaya S, Koksal i. Evaluation of clinical and laboratory predictors of fatality in patients with Hantavirus infection. J Microbiol Infect Dis. 2012;2:155-9.

31. Jonsson $\mathrm{CB}$, Hooper J, Mertz G. Treatment of hantavirus pulmonary syndrome. Antiviral Res. 2008;78:162-9.

32. Hooper JW, Moon JE, Paolino KM, Newcomer R, McLain DE, Josleyn M, Hannaman D, Schmaljohn C. A Phase 1 clinical trial of Hantaan virus and Puumala virus M-segment DNA vaccines for haemorrhagic fever with renal syndrome delivered by intramuscular electroporation. Clin Microbiol Infect. 2014;20(Suppl 5):110-7. 